\title{
EFFECTS OF GENETIC VARIATIONS OF MLCK2, AMPD1, AND COL5A1 ON MUSCLE ENDURANCE
}

\author{
EFEITOS DAS VARIAÇÕES GENÉTICAS DE MLCK2, AMPD1 E COL5A1 SOBREA RESISTÊNCIA MUSCULAR
}

ORIGINAL Article

ARTIGO ORIGINAL Artículo Original

\author{
EFECTOS DE LAS VARIACIONES GENÉTICAS DE MLCK2, AMPD1 Y COL5A1 SOBRE LA RESISTENCIA MUSCULAR
}

\begin{abstract}
Cem Horozoglu' (iD
(Molecular Medicine Professional)

Halid Emre Aslan² (D)

(Sports Science Practitioner)

Ali Karaagac $^{3}$ (iD

(Physiotherapist)

Ozlem Kucukhuseyin ${ }^{4}$ (D)

(Molecular Medicine Professional)

Tugce Bilgic ${ }^{1}$ (DD

(Physiotherapist)

Solen Himmetoglu' (iD

(Medical Biochemistry Professional)

Arezoo Gheybi ${ }^{4}$ (D)

(Molecular Medicine Professional)

Ilhan Yaylim 4 (iD)

(Molecular Medicine Professional)

Umit Zeybek ${ }^{4}$ (D)

(Molecular Medicine Professional)

1. Biruni University, School of Medicine, Department of Medical Biochemistry, Istanbul, Turkey. 2. Istanbul Gelisim University, Institute of Health Science, Department of Sports and Exercise Sciences, Istanbul, Turkey. 3. Istanbul Gelisim University, Department of Physiotherapy Techniques, Istanbul, Turkey. 4. Istanbul University, Aziz Sancar Institute of Experimental Medicine, Department of Molecular Medicine, Istanbul, Turkey.

\section{Correspondence:}

Cem Horozoğlu

Department of Medical

Biochemistry, School of Medicine,

Biruni University. Protokol

Yolu No:45, 10. Yıl Cd., 34010

Zeytinburnu, Istanbul, Turkey

chorozoglu@biruni.edu.tr
\end{abstract}

\section{ABSTRACT}

Introduction: Although potential relationships with genetic variants of MLCK2, AMPD1 and COL5A1 have been detected in molecular studies evaluating sports performance from the genetic perspective, there are limited data in terms of muscle endurance and physical fitness. Materials and Methods: This study aimed to evaluate these variants in terms of lower limb muscle endurance and physical fitness in thirty-three soccer players. Genotypes were determined by High Resolution Melting (HRM) analysis in qPCR after genomic DNA was isolated from buccal swab samples from the participants. Measurements of lower limb muscle endurance, the dynamic leap and balance test (DLBT), and the standing broad jump test (SBJ) were taken for all the participants. Results: Greater height $(p=0.006)$, higher DLBT $(p=0.016)$ and SBJ $(p=0.033)$ scores, as well as greater left hip adduction $(p<0.001)$, were detected in those with the CT genotype for AMPD1 as compared to those with CC. For MLCK rs28497577, it was found that the players carrying the AA genotype were taller $(p=0.046)$, heavier $(p=0.049)$, and had greater left knee extension $(p=0.014)$ and left foot plantar flexion ( $p=0.040$ ) than those carrying the $C$ allele. Those with the CT genotype for COL5A1 rs12722 had greater right hip extension $(p=0.040)$ and right knee extension $(p=0.048)$ than those with the CC genotype. Conclusions: Our results showed that MLCK2 and COL5A1 gene variants are associated with body composition and lower limb muscle endurance, and the presence of the AMPD1 CT genotype may contribute positively to balance, correct positioning, controlled strength, and hip mobility. Evidence level II; Comparative prospective study.

Keywords: Skeletal muscle; Athletic performance; Genetic variation.

\section{RESUMO}

Introdução: Embora tenham sido detectadas possiveis relações entre variantes genéticas de MLCK2, AMPD1 e COL5A1 em estudos moleculares que avaliam o desempenho esportivo do ponto de vista genético, os dados são limitados no que diz respeito à resistência muscular è aptidão física. Materiais e Métodos: Este estudo objetivou avaliar essas variantes quanto à resistência muscular dos membros inferiores e à aptidão física em trinta e três jogadores de futebol. Os genótipos foram determinados por análise de fusão de alta resolução (HRM) em qPCR depois de o DNA genômico ter sido isolado de amostras de esfregaço bucal dos participantes. As medidas de resistência muscular dos membros inferiores, do salto dinâmico e teste de equilíbrio (DLBT) e de testes de salto em largura parado (SBJ) foram realizadas em todos os participantes. Resultados: Estatura maior $(p=0,006)$, escores mais altos de DLBT $(p=0,016)$ eSBJ $(p=0,033)$, bem como maior adução do quadril esquerdo ( $p<0,001)$ foram detectados nos participantes com genótipo CT para AMPD1 em comparação aos com genótipo CC. Para MLCK rs28497577, verificou-se que os jogadores com genótipo AA eram mais altos $(p=0,046)$, mais pesados $(p=0,049)$, e tinham maior extensão do joelho esquerdo $(p=0,014)$ e flexão plantar do pé esquerdo $(p=0,040)$ do que os que têm o alelo C. Os jogadores com genótipo CT para COL5A1 rs 12722 tiveram maior extensão de quadril direito $(p=0,040)$ e extensão de joelho direito $(p=0,048)$ do que os com genótipo CC. Conclusões: Nossos resultados mostraram que as variantes dos genes MLCK2 e COL5A1 estão associadas à composição corporal e resistência muscular dos membros inferiores e que a presença do genótipo AMPD1 CT pode contribuir positivamente para o equilibrio, o posicionamento correto, a força controlada e a mobilidade do quadril. Nível de evidência Il; Estudo prospectivo comparativo.

Descritores: Músculo esquelético; Performance atlética; Variação genética.

\section{RESUMEN}

Introducción: Aunque se han detectado posibles relaciones entre variantes genéticas de MLCK2, AMPD1 y COL5A1 en estudios moleculares que evalúan el rendimiento atlético desde un punto de vista genético, los datos son limitados en términos de resistencia muscular y aptitud física. Materiales y Métodos: El objetivo del estudio era evaluar estas variantes en relación con la resistencia muscular de las extremidades inferiores y la aptitud física en treinta y tres jugadores de fútbol. Los genotipos se determinaron mediante análisis de fusión de alta resolución (HRM) en QPCR después de aislar el ADN genómico de las muestras de hisopos bucales de los participantes. Se realizaron mediciones 
de resistencia muscular de las extremidades inferiores, prueba de salto dinámico y equilibrio (DLBT) y pruebas de salto amplio de pie (SBJ) en todos los participantes. Resultados: Se detectó una mayor altura $(p=0,006)$, mayor puntuación $\operatorname{DLBT}(p=0,016)$ ySBJ $(p=0,033)$, asícomo una mayor aducción de la cadera izquierda $(p<0,001)$ en los participantes con genotipo CT para AMPD1 en comparación con los que tenían genotipo CC. En el caso de MLCK rs28497577, los jugadores que portaban el genotipo AA tenían mayor estatura $(p=0,046)$, mayor peso $(p=0,049)$, mayor extensión de la rodilla izquierda $(p=0,014)$ y flexión plantar del pie izquierdo $(p=0,040)$ que los que portaban el alelo C. Aquellos con genotipo CT para COL5A1 rs 12722 tenían una mayor extensión de la cadera derecha $(p=0,040)$ y de la rodilla derecha $(p=0,048)$ que aquellos con genotipo CC. Conclusiones: Nuestros resultados mostraron que las variantes de los genes MLCK2 y COL5A1 están asociadas con la composición corporal y la resistencia muscular de las extremidades inferiores y que la presencia del genotipo AMPD1 CT puede contribuir positivamente al equilibrio, el posicionamiento correcto, la fuerza controlada y la movilidad de la cadera. Nivel de evidencia ll; Estudio prospectivo comparativo.

Descriptores: Músculo esquelético; Rendimiento atlético; Variación genética.

\section{INTRODUCTION}

Sports genetics, as a sub-branch of sports physiology, aims to examine the genetic factors affecting sports performance from physiological, physical, neurological and psychological perspectives. ${ }^{1}$ In this axis, especially SNPs (Single Nucleotide Polymorphisms) are frequently used to determine advantageous or disadvantageous genotype-phenotype relationships in terms of sportive performance parameters. The genetic variants identified today contribute to the selection of athletes for team games, individual exercise planning and the development of strategies against sports injuries. ${ }^{2}$

MLCK2, an isoform of Myosin Light Chain Kinases (MLCK or MYLK), is highly expressed in fast-twitch skeletal muscle fibers. The biochemical process that begins with the binding of MLCK2 to the $\mathrm{Ca}(2+) / \mathrm{calmo}$ dulin complex results in phosphorylation of the light chain and muscle contraction. Although the MLCK mechanism has importance in smooth muscle physiology, its role and gene variants in skeletal muscle has not been fully characterized. ${ }^{3}$

In Spanish marathon runners, rs28497577, which is one of the missense genetic variants of MLCK2, wild type CC genotype was observed in 88\% and CA genotype was observed in 22\%, but mutant AA genotype was not detected. In the same study, it was observed that those carrying the CC genotype had a high serum myog lobin ratio and low muscle strength. ${ }^{4}$ It was observed that creatine kinase levels were high and muscle flexibility was weak in athletes who performed standard elbow flexion eccentric exercises and those carrying the AA genotype for rs28497577. In another study, a relationship was found between exercise intensity and increased creatine kinase levels and AA genotype, while the genotype frequency was found to be high, especially in African Americans. ${ }^{6}$

Adenosine monophosphate deaminase (AMPD), as an important regulator of cellular energy metabolism in sports biomechanics, catalyzes the deamination of adenosine monophosphate (AMP) to inosine monophosphate (IMP), shifting the balance of its reaction towards ATP formation. ' It was determined that AMPD1 deficiency and the TT genotype for rs17602729, a missense variant, were associated with low aerobic performance, 8,9 while carriage of the C allele was associated with anaerobic muscle activity, high speed and strength. ${ }^{10}$ Similarly, no significant difference was found for the rs17602729 genotypes in Israeli elite athletes, ${ }^{11}$ while the T allele carrier was associated with explosive power and speed in Polish rowers. ${ }^{12}$ In Lithuanian athletes, T allele carrier was associated with injury susceptibility and low score, and CC genotype was associated with strength and jumping ability. ${ }^{13}$ On the other hand, there was a correlation between T allele carriage and low oxygen saturation during climbing. ${ }^{14}$ In Brazilian football players, CC genotype was found to be high with running distance, and among sumo wrestlers, ${ }^{15}$ Tallele carrier was found to be high. ${ }^{16}$
Collagen $\mathrm{V}(\mathrm{COL} 5)$ has different isoforms and the most common form is A1 (COL5A1). Mutation and 3'-UTR SNPs of COL5A1, which is an important regulator of the extracellular matrix in joints, muscles, tendons and connective tissues, are reflected in the clinic in the form of elasticity problems. ${ }^{17}$

While it was determined that the functional bending test (FBT) and passive straight leg raising test (SLR) levels were low in adolescent athletes carrying the CT genotype for COL5A1 rs $12772,{ }^{18}$ this relationship was not detected in Japanese athletes. ${ }^{19}$ High risk of musculoskeletal injury and low sit and right score (SR) were determined in professional league Italian football players with TT genotype.20,21 While no association was found for the relevant SNP in Brazilian runners, ${ }^{22}$ the $C$ allele was associated with resistance to soft tissue damage in rugby players. ${ }^{23}$ In female athletes, the correlation of carrying the Tallele with muscle fatigue and damage was determined. ${ }^{24,25}$

The aim of our study is to examine together these three SNPs, which have different results in parameters such as aerobic performance, flexibility and joint mobility in various sports branches, in terms of lower extremity muscular endurance and physical fitness in football players.

\section{OBJECTIVES AND METHODS Participants}

The research sample was formed with the participation of thirty-three male super amateur league football players between the ages of 18-25 without the diagnosis of three generations of genetic diseases, history of cardiovascular disease, severe sports injury and musculoskeletal system disease. All clinical examination and laboratory measurements in selected cases were carried out in accordance with the Declaration of Helsinki (2008) with the approval of the Istanbul University Faculty of Medicine Clinical Research Ethics Committee numbered 25/01/2019-02.

\section{Biological sampling and genotyping}

For biological sampling, the participants were first asked to rinse their mouths with physiological saline and spit, and then the epithelial cells were collected by applying the swab to the inside of the cheeks 5- 6 times in an open position. After swab collection, the sample was stored at $-20^{\circ} \mathrm{C}$ until laboratory procedures began. Genomic DNA extraction was performed from the buccal swab samples taken from the participants using the QIAamp DNA Mini Kit (ID:51304, Qiagen, Germany) in accordance with the manufacturer's instructions. Spectrophotometric measurement was performed to evaluate the purity and amount of genomic DNA.

qPCR (Rotor-Gene Q Real Time PCR, Qiagen, Germany) was performed using primers F: 5'-GTGCG-GTGGACACAGCTGCCG-3've 
R: 5'-CAGCTTGGTCAA-AGACATTGAGG-3'for MLCK (rs28497577), F: 5'-CTTCATACAGCTGAAGAGACA-3've R: 5'- GAATCCAGAAAAGCCATGAGC-3' for AMPD1 (rs 17602729), F: 5'-GCAGTCAGCAGCGTGGGTCTGGTTATCT-3' ve R: 5'-TTTGGGGTGGCACTTGCAGCACTGGTCG-3' for COL5A1 (rs1277) and Type-it ${ }^{\oplus}$ HRM master mix (ID: 206544, Qiagen, Germany) from DNA samples of appropriate purity and amount. The reaction conditions were as follow: initial hold at $94^{\circ} \mathrm{C}$ for $3 \mathrm{~min}, 35$ cycles of denaturation at $94^{\circ} \mathrm{C}$ for $60 \mathrm{~s}$, annealing at $53^{\circ} \mathrm{C}$ for $60 \mathrm{~s}$ and extension at $72^{\circ} \mathrm{C}$ for 60 $\mathrm{s}$, and a final extension step of $8 \mathrm{~min}$ at $72^{\circ} \mathrm{C}$. Genotype determination was then performed by HRM analysis by fluorescence collection during a temperature ramp from $52^{\circ} \mathrm{C}$ to $95^{\circ} \mathrm{C}$ in $0.1^{\circ} \mathrm{C}$ intervals.

\section{Muscle endurance and physical fitness evaluations of the lower limbs}

Isokinetic measurements were performed using a hand dynamometer, with the subjects in suitable positions such as prone or supine for the measurement of each muscle group. Dynamic leap and balance test (DLBT) and standing wide jump tests (SBJ) were evaluated on a separate day independent of isokinetic examinations.

In the DLBT test with the subject, they stand on the dominant lower extremity while the non-dominant lower extremity is semi-flexed. The test ends if the subject cannot hold the test position. The time to stay in this position is determined by the stopwatch. The test is repeated with eyes open and closed. In the SBJ test, when the non-dominant lower extremity knee joint is semi-infected and the upper extremities are clamped behind the body, the subjects are asked to jump forward. Three measurements are made and the average is taken.

\section{Statistics}

The gene counting method was used in allele frequency. Statistical significance level was accepted as $p \leq 0.05$ using SPSS version 20 and the relationship between muscle endurance and physical performance values was evaluated with the determined genotypes $t$ and mann Whitney $U$ tests.

\section{RESULTS}

The average age of our study group was $19.38 \pm 0.99$ years. The frequency of players acoording to the to the positions they play were 14 midfielders (42\%), 10 defenders (30\%), 6 strikers (18\%) and 3 goalkeepers (10\%). The average height, weight and BMl of the players was determined as $178.68 \pm 6.51 \mathrm{~cm}, 72.37 \pm 6.68 \mathrm{~kg}$ and $22.68 \pm 1.90$, respectively. While DLBT average was $181,62 \pm 95,87 \mathrm{sec}$ with eyes open, it was determined as $21,25 \pm 8,30 \mathrm{sec}$ with eyes closed. The average of SBJ was $182.59 \pm 15.85 \mathrm{~cm}$.

The average of left hip extension was $301.25 \pm 69.73 \mathrm{Nm}$, and flexion was $403.03 \pm 54.32 \mathrm{~N}$. The left hip abduction mean was $197.68 \pm$ $40.43 \mathrm{Nm}$ and adduction was $186.68 \pm 46.13 \mathrm{~N}$. The average of left knee extension was $377.25 \pm 64.08 \mathrm{Nm}$ and flexion was $274.25 \pm 50.19 \mathrm{Nm}$. While the left ankle dorsi flexion mean was $294.96 \pm 33.19 \mathrm{~N}$, plantar flexion was $367.21 \pm 81.09 \mathrm{Nm}$. The right hip extension was found to be $303.93 \pm 52.35 \mathrm{Nm}$ and the flexion was $416.96 \pm 67.48 \mathrm{~N}$. The average abduction of the right hip was $193.75 \pm 32.40 \mathrm{Nm}$ and the adduction was $203.12 \pm 35.47 \mathrm{Nm}$. The right knee extension was found to be $391.71 \pm 56.89 \mathrm{Nm}$, while the flexion was $292.53 \pm 50.79 \mathrm{Nm}$ on average. The mean values for right ankle dorsi and plantar flexion were recorded as $296.65 \pm 34.10 \mathrm{Nm}$ and $381.75 \pm 77.12 \mathrm{Nm}$.

The genotype and allele frequency of the study group was given in Table 1. For MLCK rs28497577, two of the goalkeepers were detected in the CC genotype and one in the AA genotype. CC genotype was detected in 5 striker players and AA genotype was detected in 1 striker player. CC genotype was detected in 8 defender players, CA genotype
Table 1. The genotype and alle distribution of the study group.

\begin{tabular}{c|c|c|c|c|c}
\hline \multirow{3}{*}{ Gene variations } & $\begin{array}{c}\text { Total } \\
\text { Subjects } \\
(n=33)\end{array}$ & $\begin{array}{c}\text { Goalkeeper } \\
\text { Group } \\
(n=3)\end{array}$ & $\begin{array}{c}\text { Striker } \\
\text { Group } \\
(n=6)\end{array}$ & $\begin{array}{c}\text { Defender } \\
\text { Group } \\
(n=10)\end{array}$ & $\begin{array}{c}\text { Midfielde } \\
\text { Group } \\
(n=14)\end{array}$ \\
\hline
\end{tabular}

\begin{tabular}{|c|c|c|c|c|c|c|}
\hline \multirow{7}{*}{ 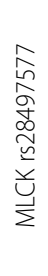 } & \multicolumn{6}{|c|}{ Genotypes } \\
\hline & CC & 26 (78.8\%) & $2(66.7 \%)$ & $5(83.3 \%)$ & 8 (80.0\%) & 11 (78.6\%) \\
\hline & $C A$ & $4(12.3 \%)$ & - & - & $1(10.0 \%)$ & $3(21.4 \%)$ \\
\hline & AA & $3(9.0 \%)$ & $1(33.3 \%)$ & $1(16.7 \%)$ & $1(10.0 \%)$ & - \\
\hline & \multicolumn{6}{|c|}{ Alleles } \\
\hline & C & 56 (84.85\%) & $4(66.7 \%)$ & $10(83.3 \%)$ & 17 (85.0\%) & $25(89.3 \%)$ \\
\hline & A & 10 (15.15\%) & $2(33.3 \%)$ & $2(16.7 \%)$ & $3(15.0 \%)$ & $3(10.7 \%)$ \\
\hline \multirow{7}{*}{ 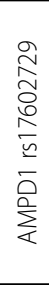 } & \multicolumn{6}{|c|}{ Genotypes } \\
\hline & CC & 30 (90.9\%) & - & $6(100.0 \%)$ & $10(100.0 \%)$ & $14(100.0 \%)$ \\
\hline & $C T$ & $3(9.1 \%)$ & $3(100.0 \%)$ & - & - & - \\
\hline & TT & - & - & - & - & - \\
\hline & \multicolumn{6}{|c|}{ Alleles } \\
\hline & C & 63 (95.5\%) & $3(50.0 \%)$ & $12(100.0 \%)$ & $20(100.0 \%)$ & $28(100.0 \%)$ \\
\hline & T & $3(4.5 \%)$ & $3(50.0 \%)$ & - & - & - \\
\hline \multirow{7}{*}{ 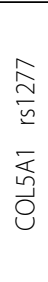 } & \multicolumn{6}{|c|}{ Genotypes } \\
\hline & CC & $23(69.7 \%)$ & $3(100.0 \%)$ & $3(50.0 \%)$ & $7(70.0 \%)$ & $10(71.4 \%)$ \\
\hline & $C T$ & $10(30.3 \%)$ & - & $3(50.0 \%)$ & $3(30.0 \%)$ & $4(28.6 \%)$ \\
\hline & TT & - & - & - & - & - \\
\hline & \multicolumn{6}{|c|}{ Alleles } \\
\hline & C & $56(84.8 \%)$ & $6(100.0 \%)$ & $9(75.0 \%)$ & 17 (85.0\%) & $24(85.7 \%)$ \\
\hline & $\mathrm{T}$ & 10 (15.2\%) & - & $3(25.0 \%)$ & $3(15.0 \%)$ & $4(14.3 \%)$ \\
\hline
\end{tabular}

The frequency of genotypes and alleles were given as numbers $(n)$ and \% values. $p$ values were not calculated among the study groups as the number of subjects were limitted.

in 1 defender and AA genotype in 1 defender. CC genotypes were detected in 11 midfielders and CA genotypes in three midfielders. For AMPD1 rs 17602729, the TT genotype was not detected in any player. The CC genotype was detected in all midfield, defender and striker players, while the $\mathrm{CT}$ genotype was detected only in goalkeepers. For the COL5A1 rs 12722 variant, none of the 33 players had the TT genotype. While CC genotype was detected in all goalkeepers $(n=3)$, CC was found in 3 strikers and CT genotype in 3 strikers. CC genotype was detected in 7 of the defending players and $\mathrm{CT}$ genotype in 3 of them. It was determined that 10 of the midfield players are in CC and 4 of them are in the CT genotype.

Table 2 shows the distribution of MLCK2 rs28497577 genotypes according to lower limb muscle endurance and physical fitness. The players carrying the AA genotype for MLCK2 rs28497577were found to have higher height $(p=0.046)$, higher weight $(p=0.049)$, higher left knee extension ( $p=0.014)$ and higher left foot plantar flexion $(p=0.040)$ than those carrying the $C$ allele.

The distribution of muscle endurance measurements and physical fitness tests according to AMPD1 rs17602729 genotypes were shown in Table 3. The players with CT genotype had longer height $(p=0.006)$, higher DLBT $(p=0.016)$ and SBJ $(p=0.033)$ score and more left hip adduction ( $p<0.001$ ) than those with CC genotype.

As shown in Table 4, the players carrying CT genotype for COL5A1 rs 12722 variant had more right hip extension $(p=0.040)$ and right knee extension ( $p=0.047$ ) than those carrying CC genotype.

\section{DISCUSSION}

The data to be obtained from sports genetics studies will contribute to the improvement of individual and team performance, to identify talented individuals in specific sports branches on the axis of genotype, and to play in the right position in team games. At the same time, a better understanding of the mechanisms of sports physiology in this axis and medical problems such as athlete injuries and injuries will contribute to the evaluation and practice processes of sports medicine. 
Table 2. Distribution of muscle endurance measurements and physical fitness tests according to genotypes of MLCK2 rs28497577.

\begin{tabular}{|c|c|c|c|}
\hline Variables & $\begin{array}{c}\text { MLCK2 } \\
\text { Genotype }\end{array}$ & $\begin{array}{c}\text { Mean } \pm \\
\text { Standard Error }\end{array}$ & $p$ value \\
\hline Height (cm) & $\begin{array}{c}\text { AA } \\
\text { CAllele }\end{array}$ & $\begin{array}{c}187.5 \pm 0.5 \\
178.1 \pm 1.14 \\
\end{array}$ & 0.046 \\
\hline Weight (kg) & $\begin{array}{c}\text { AA } \\
\text { CAllele }\end{array}$ & $\begin{array}{l}75.5 \pm 5.5 \\
72.2 \pm 1.2 \\
\end{array}$ & 0.049 \\
\hline BMl & $\begin{array}{c}\text { AA } \\
\text { C Allele }\end{array}$ & $\begin{array}{l}21.5 \pm 1.4 \\
22.8 \pm 0.3\end{array}$ & 0.353 \\
\hline Waist circumference (cm) & $\begin{array}{c}\text { AA } \\
\text { CAllele }\end{array}$ & $\begin{array}{l}78.5 \pm 1.5 \\
79.3 \pm 0.9 \\
\end{array}$ & 0.829 \\
\hline DLBT - Eyes Open (sec) & $\begin{array}{c}\text { AA } \\
\text { CAllele } \\
\end{array}$ & $\begin{array}{c}256.5 \pm 43.5 \\
176.6 \pm 18.17 \\
\end{array}$ & 0.276 \\
\hline DLBT - Eyes Closed (sec) & $\begin{array}{c}\text { AA } \\
\text { CAllele }\end{array}$ & $\begin{array}{l}29.0 \pm 2.1 \\
20.7 \pm 5.2 \\
\end{array}$ & 0.695 \\
\hline $\mathrm{SBJ}(\mathrm{cm})$ & $\begin{array}{c}\text { AA } \\
\text { C Allele }\end{array}$ & $\begin{array}{l}194.0 \pm 4.0 \\
181.8 \pm 2.9 \\
\end{array}$ & 0.301 \\
\hline Left Hip extension (Nm) & $\begin{array}{c}\text { AA } \\
\text { CAllele }\end{array}$ & $\begin{array}{c}307.5 \pm 12.5 \\
300.8 \pm 13.14 \\
\end{array}$ & 0.731 \\
\hline Left Hip flexion (Nm) & $\begin{array}{c}\text { AA } \\
\text { CAllele }\end{array}$ & $\begin{array}{l}420.0 \pm 50.0 \\
401.9 \pm 9.93 \\
\end{array}$ & 0.656 \\
\hline Left Hip Abduction (Nm) & $\begin{array}{c}\text { AA } \\
\text { CAllele } \\
\end{array}$ & $\begin{array}{c}177.5 \pm 27.5 \\
199.0 \pm 7.4 \\
\end{array}$ & 0.475 \\
\hline Left Hip Adduction (Nm) & $\begin{array}{c}\text { AA } \\
\text { C Allele }\end{array}$ & $\begin{array}{l}185.5 \pm 45.4 \\
186.8 \pm 8.43 \\
\end{array}$ & 0.971 \\
\hline Left Knee Extension (Nm) & $\begin{array}{c}\text { AA } \\
\text { CAllele }\end{array}$ & $\begin{array}{c}404.0 \pm 1.0 \\
375.5 \pm 12.02\end{array}$ & 0.014 \\
\hline Left Knee Flexion (Nm) & $\begin{array}{c}\text { AA } \\
\text { CAllele }\end{array}$ & $\begin{array}{l}258.0 \pm 58.0 \\
275.3 \pm 9.02 \\
\end{array}$ & 0.644 \\
\hline Left Ankle Dorsi Flexion (Nm) & $\begin{array}{c}\text { AA } \\
\text { CAllele }\end{array}$ & $\begin{array}{l}292.0 \pm 32.0 \\
295.2 \pm 6.07 \\
\end{array}$ & 0.899 \\
\hline Left Ankle Plantar Flexion (Nm) & $\begin{array}{c}\text { AA } \\
\text { CAllele }\end{array}$ & $\begin{array}{c}460.0 \pm 20.0 \\
361.0 \pm 14.57\end{array}$ & 0.040 \\
\hline Right Hip Extension (Nm) & $\begin{array}{c}\text { AA } \\
\text { C Allele }\end{array}$ & $\begin{array}{l}330.0 \pm 50.0 \\
302.2 \pm 9.50\end{array}$ & 0.476 \\
\hline Right Hip Flexion (Nm) & $\begin{array}{c}\text { AA } \\
\text { CAllele }\end{array}$ & $\begin{array}{r}445.0 \pm 65.0 \\
415.1 \pm 12.27 \\
\end{array}$ & 0.576 \\
\hline Right Hip Abduction (Nm) & $\begin{array}{c}\text { AA } \\
\text { CAllele }\end{array}$ & $\begin{array}{l}181.0 \pm 11.0 \\
194.6 \pm 6.06 \\
\end{array}$ & 0.486 \\
\hline Right Hip Adduction (Nm) & $\begin{array}{c}\text { AA } \\
\text { CAllele }\end{array}$ & $\begin{array}{l}160.0 \pm 30.0 \\
206.0 \pm 6.18\end{array}$ & 0.193 \\
\hline Right Knee Extension (Nm) & $\begin{array}{c}\text { AA } \\
\text { CAllele }\end{array}$ & $\begin{array}{l}410.0 \pm 20.0 \\
390.5 \pm 10.6\end{array}$ & 0.320 \\
\hline Right Knee Flexion (Nm) & $\begin{array}{c}\text { AA } \\
\text { CAllele }\end{array}$ & $\begin{array}{l}295.0 \pm 85.0 \\
292.4 \pm 8.67 \\
\end{array}$ & 0.838 \\
\hline Right Ankle Dorsi Flexion (Nm) & $\begin{array}{c}\text { AA } \\
\text { C Allele } \\
\end{array}$ & $\begin{array}{l}307.5 \pm 7.50 \\
295.9 \pm 35.1 \\
\end{array}$ & 0.254 \\
\hline Right Ankle Plantar Flexion (Nm) & $\begin{array}{c}\text { AA } \\
\text { C Allele }\end{array}$ & $\begin{array}{c}460.0 \pm 40.0 \\
382.9 \pm 13.98\end{array}$ & 0.184 \\
\hline
\end{tabular}

The Student's t-test were used to determine the significance between genotypes. BMI, body mass index: $D L B T$ the dynamic leap and balance test; SBJ, standing broad jump tests; Nm, Newton-meter. Bold values of $\mathrm{p}<0.05$ were accepted as statistically significant.

Despite its high expression in fast-twitch muscle fibers, we think that MLCK2, which has little information about its physiological mechanism, may be a factor supporting innervation in skeletal muscle. For MLCK2 rs 28497577, it was determined that although the CC genotype was advantageous in terms of muscle strength in marathon runners, the AA genotype provided an advantage in terms of body composition, left knee extension, and left foot plantar flexion. ${ }^{4}$ There are some differences in terms of movement biomechanics in runners and football players, the group in which the lower extremity is actively used. While the movement that starts with explosive energy in marathon runners continues with acceleration, it continues as intermittent and sudden fluctuations in football players. In this axis, it can be thought that the AA
Table 3. Distribution of muscle endurance measurements and physical fitness tests according to genotypes of AMPD1 rs17602729.

\begin{tabular}{|c|c|c|c|}
\hline Variables & $\begin{array}{c}\text { AMPD1 } \\
\text { Genotype }\end{array}$ & $\begin{array}{c}\text { Mean } \pm \\
\text { Standard Error }\end{array}$ & $p$ value \\
\hline Height (cm) & $\begin{array}{l}\text { CC } \\
\text { CT }\end{array}$ & $\begin{array}{l}177.9 \pm 6.3 \\
186.7 \pm 1.5\end{array}$ & 0.006 \\
\hline Weight (kg) & $\begin{array}{l}\mathrm{CC} \\
\mathrm{CT} \\
\end{array}$ & $\begin{array}{l}72.7 \pm 6.8 \\
69.7 \pm 5.5 \\
\end{array}$ & 0.470 \\
\hline BMl & $\begin{array}{l}\mathrm{CC} \\
\mathrm{CT}\end{array}$ & $\begin{array}{l}23.0 \pm 1.7 \\
20,0 \pm 1.3\end{array}$ & 0.07 \\
\hline Waist circumference (cm) & $\begin{array}{l}C C \\
C T\end{array}$ & $\begin{array}{l}79.5 \pm 5.1 \\
77.0 \pm 3.0 \\
\end{array}$ & 0.422 \\
\hline DLBT - Eyes Open (sec) & $\begin{array}{l}\mathrm{CC} \\
\mathrm{CT} \\
\end{array}$ & $\begin{array}{c}168.3 \pm 68.1 \\
310.0 \pm 105.3 \\
\end{array}$ & 0.016 \\
\hline DLBT - Eyes Closed (sec) & $\begin{array}{l}\mathrm{CC} \\
\mathrm{CT} \\
\end{array}$ & $\begin{array}{l}17.7 \pm 3.7 \\
55.7 \pm 5.7 \\
\end{array}$ & 0.096 \\
\hline $\mathrm{SBJ}(\mathrm{cm})$ & $\begin{array}{l}\mathrm{CC} \\
\mathrm{CT}\end{array}$ & $\begin{array}{c}181.0 \pm 15.7 \\
198.3 \pm 5.5 \\
\end{array}$ & 0.033 \\
\hline Left Hip extension (Nm) & $\begin{array}{l}\mathrm{CC} \\
\mathrm{CT} \\
\end{array}$ & $\begin{array}{l}301.9 \pm 73.2 \\
295.0 \pm 15.0\end{array}$ & 0.874 \\
\hline Left Hip flexion (Nm) & $\begin{array}{l}\mathrm{CC} \\
\mathrm{CT}\end{array}$ & $\begin{array}{l}406.6 \pm 55.2 \\
368.3 \pm 32.5 \\
\end{array}$ & 0.252 \\
\hline Left Hip Abduction (Nm) & $\begin{array}{l}\mathrm{CC} \\
\mathrm{CT} \\
\end{array}$ & $\begin{array}{l}196.7 \pm 42.1 \\
207.0 \pm 20.1 \\
\end{array}$ & 0.682 \\
\hline Left Hip Adduction (Nm) & $\begin{array}{l}\mathrm{CC} \\
\mathrm{CT}\end{array}$ & $\begin{array}{c}182.1 \pm 46.1 \\
231.0 \pm 1.0 \\
\end{array}$ & $<0.001$ \\
\hline Left Knee Extension (Nm) & $\begin{array}{l}\text { CC } \\
\text { CT }\end{array}$ & $\begin{array}{l}374.6 \pm 64.5 \\
403.3 \pm 65.5\end{array}$ & 0.468 \\
\hline Left Knee Flexion (Nm) & $\begin{array}{l}\mathrm{CC} \\
\mathrm{CT} \\
\end{array}$ & $\begin{array}{l}269.9 \pm 50.6 \\
316.3 \pm 16.5\end{array}$ & 0.129 \\
\hline Left Ankle Dorsi Flexion (Nm) & $\begin{array}{l}\mathrm{CC} \\
\mathrm{CT} \\
\end{array}$ & $\begin{array}{l}292.0 \pm 32.9 \\
324.0 \pm 24.0\end{array}$ & 0.113 \\
\hline Left Ankle Plantar Flexion (Nm) & $\begin{array}{l}C C \\
C T\end{array}$ & $\begin{array}{l}359.7 \pm 80.9 \\
440.0 \pm 40.0 \\
\end{array}$ & 0.103 \\
\hline Right Hip Extension (Nm) & $\begin{array}{l}\mathrm{CC} \\
\mathrm{CT} \\
\end{array}$ & $\begin{array}{l}305.8 \pm 53.7 \\
285.7 \pm 38.8 \\
\end{array}$ & 0.534 \\
\hline Right Hip Flexion (Nm) & $\begin{array}{l}\mathrm{CC} \\
\mathrm{CT} \\
\end{array}$ & $\begin{array}{l}421.9 \pm 68.3 \\
369.0 \pm 37.7 \\
\end{array}$ & 0.201 \\
\hline Right Hip Abduction (Nm) & $\begin{array}{l}\mathrm{CC} \\
\mathrm{CT} \\
\end{array}$ & $\begin{array}{l}193.9 \pm 33.9 \\
192.3 \pm 12.5 \\
\end{array}$ & 0.938 \\
\hline Right Hip Adduction (Nm) & $\begin{array}{l}C C \\
C T\end{array}$ & $\begin{array}{l}204.4 \pm 36.8 \\
190.3 \pm 15.5 \\
\end{array}$ & 0.521 \\
\hline Right Knee Extension (Nm) & $\begin{array}{l}\mathrm{CC} \\
\mathrm{CT}\end{array}$ & $\begin{array}{l}391.9 \pm 58.9 \\
390.0 \pm 40.0\end{array}$ & 0.957 \\
\hline Right Knee Flexion (Nm) & $\begin{array}{l}\mathrm{CC} \\
\mathrm{CT} \\
\end{array}$ & $\begin{array}{l}290.4 \pm 49.5 \\
313.3 \pm 70.2 \\
\end{array}$ & 0.465 \\
\hline Right Ankle Dorsi Flexion (Nm) & $\begin{array}{l}\mathrm{CC} \\
\mathrm{CT} \\
\end{array}$ & $\begin{array}{l}296.2 \pm 35.6 \\
301.0 \pm 16.5 \\
\end{array}$ & 0.821 \\
\hline Right Ankle Plantar Flexion (Nm) & $\begin{array}{l}\text { CC } \\
\text { CT }\end{array}$ & $\begin{array}{l}384.4 \pm 79.7 \\
420.0 \pm 40.0\end{array}$ & 0.456 \\
\hline
\end{tabular}

The Student's t-test were used to determine the significance between genotypes. BMI, body mass index: $D L B T$ the dynamic leap and balance test; SBJ, standing broad jump tests; Nm, Newton-meter. Bold values of $p<0.05$ were accepted as statistically significant.

genotype contributes to short-term sudden contractions such as strut. In our study, the highest rate of A allele among all positions in goalkeepers with $33.3 \%$ supports this idea. Frequency of A allele was observed as $16.7 \%$ in strikers, $10 \%$ in defense and $0 \%$ in midfielders. Considering that midfielders cover more distance than defenders and strikers, but the type of activity is mild to moderately prolonged, it makes us think that $\mathrm{A}$ allele carrier is not advantageous for this position.

It has been reported in the literature that the AA genotype may be associated with high creatine kinase level, loss of flexibility, and muscle damage. ${ }^{5,6}$ Hypertrophy, which occurs as a result of exercises aimed at developing regional muscles, is associated with increased creatine kinase level, and it reaches a critical level in case of muscle damage. 
Table 4. Distribution of muscle endurance measurements and physical fitness tests according to genotypes of COL5A1 rs 12722 .

\begin{tabular}{|c|c|c|c|}
\hline Variables & $\begin{array}{l}\text { COL5A1 } \\
\text { Genotype }\end{array}$ & $\begin{array}{c}\text { Mean } \pm \\
\text { Standard Error }\end{array}$ & $p$ value \\
\hline Height (cm) & $\begin{array}{l}\mathrm{CC} \\
\mathrm{CT}\end{array}$ & $\begin{array}{l}178.2 \pm 1.5 \\
179.8 \pm 5.1\end{array}$ & 0.524 \\
\hline Weight (kg) & $\begin{array}{l}\mathrm{CC} \\
\mathrm{CT}\end{array}$ & $\begin{array}{l}71.5 \pm 1.4 \\
74.3 \pm 2.1 \\
\end{array}$ & 0.279 \\
\hline BMI & $\begin{array}{l}\mathrm{CC} \\
\mathrm{CT}\end{array}$ & $\begin{array}{l}22.5 \pm 0.41 \\
23.0 \pm 0.58\end{array}$ & 0.533 \\
\hline Waist circumference (cm) & $\begin{array}{l}\mathrm{CC} \\
\mathrm{CT}\end{array}$ & $\begin{array}{l}78.9 \pm 1.10 \\
80.1 \pm 1.53\end{array}$ & 0.561 \\
\hline DLBT - Eyes Open (sec) & $\begin{array}{l}\mathrm{CC} \\
\mathrm{CT} \\
\end{array}$ & $\begin{array}{l}189.7 \pm 22.62 \\
163.9 \pm 26.23 \\
\end{array}$ & 0.503 \\
\hline DLBT - Eyes Closed (sec) & $\begin{array}{l}\mathrm{CC} \\
\mathrm{CT}\end{array}$ & $\begin{array}{l}25.5 \pm 6.75 \\
11.9 \pm 5.21 \\
\end{array}$ & 0.213 \\
\hline $\mathrm{SBJ}(\mathrm{cm})$ & $\begin{array}{l}\mathrm{CC} \\
\mathrm{CT}\end{array}$ & $\begin{array}{l}182.7 \pm 3.65 \\
182.3 \pm 4.22 \\
\end{array}$ & 0.945 \\
\hline Left Hip extension (Nm) & $\begin{array}{l}\mathrm{CC} \\
\mathrm{CT} \\
\end{array}$ & $\begin{array}{l}287.6 \pm 13.58 \\
331.2 \pm 24.14 \\
\end{array}$ & 0.102 \\
\hline Left Hip flexion (Nm) & $\begin{array}{l}\mathrm{CC} \\
\mathrm{CT}\end{array}$ & $\begin{array}{c}401.2 \pm 9.89 \\
407.1 \pm 22.60\end{array}$ & 0.708 \\
\hline Left Hip Abduction (Nm) & $\begin{array}{l}\mathrm{CC} \\
\mathrm{CT}\end{array}$ & $\begin{array}{c}194.7 \pm 9.16 \\
204.2 \pm 11.17 \\
\end{array}$ & 0.548 \\
\hline Left Hip Adduction (Nm) & $\begin{array}{l}\mathrm{CC} \\
\mathrm{CT}\end{array}$ & $\begin{array}{l}181.7 \pm 10.41 \\
197.7 \pm 12.51 \\
\end{array}$ & 0.371 \\
\hline Left Knee Extension (Nm) & $\begin{array}{l}\mathrm{CC} \\
\mathrm{CT}\end{array}$ & $\begin{array}{l}368.4 \pm 13.21 \\
396.7 \pm 21.36 \\
\end{array}$ & 0.254 \\
\hline Left Knee Flexion (Nm) & $\begin{array}{l}\mathrm{CC} \\
\mathrm{CT}\end{array}$ & $\begin{array}{c}274.6 \pm 9.20 \\
273.5 \pm 20.80 \\
\end{array}$ & 0.956 \\
\hline Left Ankle Dorsi Flexion (Nm) & $\begin{array}{l}\mathrm{CC} \\
\mathrm{CT}\end{array}$ & $\begin{array}{l}299.6 \pm 7.52 \\
284.7 \pm 8.49 \\
\end{array}$ & 0.244 \\
\hline Left Ankle Plantar Flexion (Nm) & $\begin{array}{l}\mathrm{CC} \\
\mathrm{CT}\end{array}$ & $\begin{array}{l}368.5 \pm 16.18 \\
364.5 \pm 30.32 \\
\end{array}$ & 0.901 \\
\hline Right Hip Extension (Nm) & $\begin{array}{l}\mathrm{CC} \\
\mathrm{CT} \\
\end{array}$ & $\begin{array}{c}291.3 \pm 8.81 \\
331.8 \pm 20.47 \\
\end{array}$ & 0.040 \\
\hline Right Hip Flexion (Nm) & $\begin{array}{l}\mathrm{CC} \\
\mathrm{CT}\end{array}$ & $\begin{array}{l}410.7 \pm 14.61 \\
430.7 \pm 21.03\end{array}$ & 0.447 \\
\hline Right Hip Abduction (Nm) & $\begin{array}{l}\mathrm{CC} \\
\mathrm{CT} \\
\end{array}$ & $\begin{array}{c}196.3 \pm 7.03 \\
188.1 \pm 10.13 \\
\end{array}$ & 0.515 \\
\hline Right Hip Adduction (Nm) & $\begin{array}{l}\mathrm{CC} \\
\mathrm{CT}\end{array}$ & $\begin{array}{c}197.7 \pm 7.47 \\
215.0 \pm 11.13\end{array}$ & 0.207 \\
\hline Right Knee Extension (Nm) & $\begin{array}{l}\mathrm{CC} \\
\mathrm{CT}\end{array}$ & $\begin{array}{l}379.0 \pm 10.34 \\
419.7 \pm 20.94 \\
\end{array}$ & 0.050 \\
\hline Right Knee Flexion (Nm) & $\begin{array}{l}\mathrm{CC} \\
\mathrm{CT} \\
\end{array}$ & $\begin{array}{l}298.6 \pm 10.55 \\
279.1 \pm 16.96 \\
\end{array}$ & 0.321 \\
\hline Right Ankle Dorsi Flexion (Nm) & $\begin{array}{l}\mathrm{CC} \\
\mathrm{CT}\end{array}$ & $\begin{array}{l}295.5 \pm 6.73 \\
299.3 \pm 40.8 \\
\end{array}$ & 0.773 \\
\hline Right Ankle Plantar Flexion (Nm) & $\begin{array}{l}\mathrm{CC} \\
\mathrm{CT}\end{array}$ & $\begin{array}{l}381.9 \pm 16.33 \\
400.6 \pm 25.54\end{array}$ & 0.534 \\
\hline
\end{tabular}

The Student's t-test were used to determine the significance between genotypes. BML body mass index: DLBT the dynamic leap and balance test; SBJ, standing broad jump tests; Nm, Newton-meter. Bold values of $p<0.05$ were accepted as statistically significant.

In the ambivalent situation, which can be seen as the disadvantage of the advantage in terms of muscle hypertrophy, non-intensive and time-spread exercises may be preferred, especially in those with the AA genotype in this SNP.

It has been determined that the $C$ allele for the rs 17602729 variant of AMPD1, which also plays a role in AMP deamination, is associated with speed and strength in many different sports branches, and the Tallele carrier frequency has been reported to be over 13\%.10,11,12 In our study, it is seen that the T allele frequency is approximately $4.5 \%$ in Turkish football players. While TT genotype was not found in any football player, it was determined that all goalkeepers were in CT genotype. Examining the relationship between genetic variants and sports injuries in male soccer players, the study found that $\mathrm{TT}$ and $\mathrm{CT}$ genotypes were associated with injury risk and low match scores for AMPD1 rs $17602729 .{ }^{26}$ In Lithuanian elite athletes, significant relationships were found in terms of total genotype score consisting of genetic markers and susceptibility to athletic performance, which were examined in endurance-strength mixed logistic regression models, in terms of gender, endurance and strength. For AMPD1 rs 17602729, one of these genetic markers, TT genotype was detected in only two cases in the sample, and data indicating that it may be associated with power score were determined. ${ }^{27}$ In support of these studies, it was determined in our study that balance and lower extremity muscle groups were associated with endurance in football players carrying the CT genotype. Significant differences were found in multi-locus interaction studies, including AMPD1 rs17602729, in Polish male marathon runners classified according to marathon running time. In addition, similar to our study, the CC genotype was dominant in the sample, and it was determined that $\mathrm{T}$ allele carriage completed faster running distance than those carrying $\mathrm{CC} .{ }^{28} \mathrm{Although}$ the literature data and our own findings suggest that carrying the T allele provides an advantage in terms of running and strength, it should be noted that potential power may be an additional factor triggering sports injuries if correct positioning and control are not applied. If we look at this situation in terms of the fact that the goalkeepers remain passive during the game and short-term explosive power use compared to other position players, it suggests that the CT genotype may be an important factor in balancing speed and power.

The genotype distribution for the rs 12722 variant of COL5A1, one of the extracellular matrix regulators, could not be found to be associated with musculoskeletal injury in Polish football players ${ }^{29}$ and Caucasian races between those who show intense physical activity and those who are sedentary. ${ }^{30}$ On the other hand, in studies in which the COL5A1 rs12722 variant was evaluated on the axis of physical performance, it was determined that it showed a negative correlation with FBT and SLR scores in athletes with CT genotype, ${ }^{18}$ and in another study, it was determined that TT genotype was associated with SLR and SR scores. ${ }^{20}$ Although we did not detect TT genotype in our study, CT genotype was observed at a rate of $30.3 \%$. While CT genotype was not detected in goalkeepers, the highest CT genotype carrier was observed in striker (50.0\%), defender (30.0\%) and midfielder (28.6\%). Considering that strikers perform longer sprints than midfielders and defenders, it is thought that $\mathrm{CT}$ genotype carrier may have a functionalizer effect on lower extremity muscle endurance. Considering that the TT genotype increases the risk of musculoskeletal injury in Italian football players, ${ }^{21}$ and the relationship between $\mathrm{C}$ allele carriage and resistance to soft tissue damage in another study ${ }^{23,25}$ suggests that the CT heterozygous genotype may be a balancing factor in terms of balanced muscle power use. Although there were original and first reported data in our study, the low number of cases and the fact that the muscle endurance measurements were not evaluated together with genotypes before and after applying a special training model for lower extremity muscle endurance are limiting factors.

\section{CONCLUSION}

Although we performed our study in a small sample, mutant allele or heterozygous genotype was detected in all SNPs of MLCK2, AMPD1 and COL5A1. Allele and genotype frequencies are similar to the rates obtained in different sports branches in the literature. In MLCK2 rs28497577 variant, height, weight, knee extension and ankle plantar flexion were found to be significantly higher in those carrying mutant AA genotypes compared to other genotypes. In AMPD1 rs17602729 variant, height, balance time, jump distance, hip adduction were found 
to be significantly higher in heterozygous CT patients. In the COL5A1 rs 12722 variant, the significantly higher difference was in the direction of hip and knee extension in those with CT.

In the light of these data, we think that mutant alleles or genotypes of the three SNPs may have functional effects in terms of muscle endurance and physical fitness. It should not be hoped that this situation may increase the injury and disability of the athlete due to excessive uncontrolled movements with the effect of excessive hypertrophic response and psychosomatic factors.

All authors declare no potential conflict of interest related to this article

AUTHORS' CONTRIBUTIONS: Each author has made a significant personal contribution to the article. Cem Horozoğlu designed the study, analyzed the data and wrote the article. HEA and AK performed muscle endurance measurements. TB evaluated the physiotherapy results presented in the article. AG carried out laboratory studies. SH edited the tables and sources of the article. ÜZi Y and ÖK provided consultancy on statistical evaluations. CH is a corresponding author in working setup, experimental stages and article writing. The final manuscript has been read and approved by all authors.

\section{REFERENCES}

1. Tanisawa K, Wang G, Seto J, Verdouka I, Twycross-Lewis R, Karanikolou A, et al. Sport and exercise genomics: the FIMS 2019 consensus statement update. Br J Sports Med. 2020;54(16):969-75.

2. Collins M, O"Connell K, Posthumus M. Genetics of Musculoskeletal Exercise-Related Phenotypes. Med Sport Sci. 2016;61:92-104.

3. McCarthy MR, Savich Y, Cornea RL, Thomas DD. Resolved Structural States of Calmodulin in Regulation of Skeletal Muscle Calcium Release. Biophys J. 2020;1 18(5):1090-100.

4. Del Coso J, Valero M, Lara B, Salinero JJ, Gallo-Salazar C, Areces F. Myosin Light Chain Kinase (MLCK) Gene Influences Exercise Induced Muscle Damage during a Competitive Marathon. PLoS One. 2016;2;11 (8):e0160053.

5. Clarkson PM, Hoffman EP, Zambraski E, Gordish-Dressman H, Kearns A, Hubal M, et al. ACTN3 and MLCK genotype associations with exertional muscle damage. J Appl Physiol (1985). 2005;99(2):564-9.

6. Landau ME, Kenney K, Deuster P, Gonzalez RS, Contreras-Sesvold C, Sambuughin N, et al. Investigation of the relationship between serum creatine kinase and genetic polymorphisms in military recruits. Mil Med. 2012:177(11):1359-65

7. Rubio JC, Martín MA, Rabadán M, Gómez-Gallego F, San Juan AF, Alonso JM, et al. Frequency of the C34T mutation of the AMPD1 gene in world-class endurance athletes: does this mutation impair performance? J Appl Physiol (1985). 2005;98(6):2108-12.

8. Fischer H, Esbjörnsson M, Sabina RL, Strömberg A, Peyrard-Janvid M, Norman B. AMP deaminase deficiency is associated with lower sprint cycling performance in healthy subjects. J Appl Physiol (1985). 2007;103(1):315-22.

9. Lucia A, Martin MA, Esteve-Lanao J, San Juan AF, Rubio JC, Oliván J, et al. C34T mutation of the AMPD1 gene in an elite white runner. Br J Sports Med. 2006;40(3):e7.

10. Fedotovskaya ON, Danilova AA, Akhmetov II. Effect of AMPD1 gene polymorphism on muscle activity in humans. Bull Exp Biol Med. 2013;154(4):489-91.

11. Meckel Y, Nemet D, Alves AJ. The AMPD1 C34T mutation is not associated with the status of Israeli athletes. Eur J Sport Sci. 2012;12(3):244-8.

12. Cięszczyk P, Eider J, Ostanek M, Leońska-Duniec A, Ficek K, Kotarska K, et al. Is the C34T polymorphism of the AMPD1 gene associated with athlete performance in rowing? Int J Sports Med. 2011;32(12):987-91.

13. Ginevičienè V, Jakaitienè A, Pranculis A, Milašius K, Tubelis L, Utkus A. AMPD1 rs17602729 is associated with physical performance of sprint and power in elite Lithuanian athletes. BMC Genet. 2014;15:58.

14. Thomaes T, Thomis M, Onkelinx S, Fagard R, Matthijs G, Buys R, et al. A genetic predisposition score for muscular endophenotypes predicts the increase in aerobic power after training: the CAREGENE study. BMC Genet. 2011;12:84.

15. Dionísio TJ, Thiengo CR, Brozoski DT, Dionísio EJ, Talamoni GA, Silva RB, et al. The influence of genetic polymorphisms on performance and cardiac and hemodynamic parameters among Brazilian soccer players. Appl Physiol Nutr Metab. 2017;42(6):596-604.

16. Bondareva EA, Godina EZ. Search for association between C/Tpolymorphism of AMPD1 gene and sports achievement in sambo wrestling. Theory and Practice of Physical Culture. 2016;6:13-13
17. Khoshnoodi J, Cartailler JP, Alvares K, Veis A, Hudson BG. Molecular recognition in the assembly of collagens: terminal noncollagenous domains are key recognition modules in the formation of triple helical protomers. J Biol Chem. 2006;281(50):38117-21.

18. Stastny P, Lehnert M, De Ste Croix M, Petr M, Svoboda Z, Maixnerova E, et al. Effect of COL5A1, GDF5, and PPARA Genes on a Movement Screen and Neuromuscular Performance in Adolescent Team Sport Athletes. J Strength Cond Res. 2019;33(8):2057-65.

19. Miyamoto-Mikami E, Miyamoto N, Kumagai H, Hirata K, Kikuchi N, Zempo H, et al. COL5A1 rs12722 polymorphism is not associated with passive muscle stiffness and sports-related muscle injury in Japanese athletes. BMC Med Genet. 2019;20(1):192.

20. Collins M, Mokone GG, September AV, van der Merwe L, Schwellnus MP. The COL5A1 genotype is associated with range of motion measurements. Scand J Med Sci Sports. 2009;19(6):803-10.

21. Massidda M, Bachis V, Corrias L, Piras F, Scorcu M, Calò CM. Influence of the COL5A1 rs12722 on musculoskeletal injuries in professional soccer players. J Sports Med Phys Fitness. 2015;55(11):1348-53.

22. Bertuzzi R, Pasqua LA, Bueno S, Lima-Silva AE, Matsuda M, Marquezini M, et al. Is the COL5A1 rs12722 gene polymorphism associated with running economy? PLoS One. 2014;9(9):e106581.

23. Heffernan SM, Kilduff LP, Erskine RM, Day SH, Stebbings GK, Cook CJ, et al. COL5A1 gene variants previously associated with reduced soft tissue injury risk are associated with elite athlete status in rugby. BMC Genomics. 2017;18(suppl 8):820.

24. Sivertsen EA, Haug KBF, Kristianslund EK, Trøseid AS, Parkkari J, Lehtimäki T, et al. No Association Between Risk of Anterior Cruciate Ligament Rupture and Selected Candidate Collagen Gene Variants in Female Elite Athletes From High-Risk Team Sports. Am J Sports Med. 2019;47(1):52-8.

25. Baumert P, G-REX Consortium, Stewart CE, Lake MJ, Drust B, Erskine RM. Variations of collagen-encoding genes are associated with exercise-induced muscle damage. Physiol Genomics. 2018;50(9):691-3.

26. McCabe K, Collins C. Can Genetics Predict Sports Injury? The Association of the Genes GDF5, AMPD1, COL5A1 and IGF2 on Soccer Player Injury Occurrence. Sports (Basel). 2018;6(1):21.

27. Pranckeviciene E, Gineviciene V, Jakaitiene A, Januska L, Utkus A. Total Genotype Score Modelling of Polygenic Endurance-Power Profiles in Lithuanian Elite Athletes. Genes (Basel). 2021;12(7):1067.

28. Gronek P, Gronek J, Lulińska-Kuklik E, Spieszny M, Niewczas M, Kaczmarczyk M, et al. Polygenic Study of Endurance-Associated Genetic Markers NOS3 (Glu298Asp), BDKRB2 (-9/+9), UCP2 (Ala55Val), AMPD1 (GIn45Ter) and ACE (I/D) in Polish Male Half Marathoners. J Hum Kinet. 2018;64:87-98.

29. Lulińska-Kuklik E, Rahim M, Domańska-Senderowska D, Ficek K, Michałowska-Sawczyn M, Moska W, et al. Interactions between COL5A1 gene and risk of the anterior cruciate ligament rupture. J Hum Kinet. 2018;62:65-71.

30. Leźnicka K, Żyżniewska-Banaszak E, Gębska M, Machoy-Mokrzyńska A, Krajewska-Pędzik A, Maciejewska-Skrendo A, et al. Interactions between Gene Variants within the COL1A1 and COL5A1 Genes and Musculoskeletal Injuries in Physically Active Caucasian. Genes (Basel). 2021;12(7):1056. 